\title{
PENGARUH PERNIKAHAN DINI DALAM KEHARMONISAN KELUARGA
}

\author{
Imamul Arifin ${ }^{1}$, Akmal Nurhidayat $^{2}$, Marjoko Panji Santoso ${ }^{3}$ \\ Politeknik Elektronika Negeri Surabaya, Teknik Mekatronika \\ Email: imamul@pens.ac.id
}

\begin{abstract}
ABSTRAK
Hadirnya Pandemi COVID-19 menjadi salah satu penyebab terjadinya kenaikan kasus pernikahan dini di indonesia. Hal ini terjadi akibat terdampaknya sektor ekonomi di beberapa lapisan kasta masyarakat. Pernikahan dini sendiri merupakan pernikahan yang dilakukan oleh pasangan yang dikategorikan anak-anak atau remaja yang berusia dibawah 19 tahun. Adapun topik yang dibahas dalam penelitian ini adalah Pengaruh Pernikahan Dini Dalam Keharmonisan Keluarga. Dalam penelitian ini pengumpulan data dilakukan dengan menggunakan metode kuantitatif. Berdasarkan data yang diambil dari 7 pasangan responden, dapat disimpulkan bahwa pernikahan dini memiliki pengaruh terhadap keharmonisan keluarga. Pernikahan dini juga dikatakan dapat mengakibatkan banyak konflik yang terjadi di dalam keluarga. Hal ini disebabkan oleh belum stabilnya emosi yang dimiliki baik dari pihak suami maupun pihak istri.
\end{abstract}

Kata kunci: Pernikahan dini, keharmonisan, keluarga

\begin{abstract}
The presence of the COVID-19 pandemic is one of the causes of the increase in cases of early marriage in Indonesia. This is its impact to the economic sector in several castes of society. Early marriage itself is a marriage carried out by couples who are categorized as children or adolescents under the age of 19 years. The topic discussed in this study is the Effect of Early Marriage on Family Harmony. In this study, data collection was carried out using quantitative methods. Based on data taken from 7 pairs of respondents, it can be concluded that early marriage influences family harmony. Early marriage is also said to lead to a lot of conflict in the family. This is due to the unstable emotions that are owned by both the husband and wife.
\end{abstract}

Keywords: early marriage, Harmony, Family 


\section{PENDAHULUAN}

\section{A. Latar Belakang}

Pandemi COVID-19 yang sedang melanda dunia sejak awal 2020 tidak hanya mengancam sektor kesehatan, namun juga mengancam pernikahan dini semakin meningkat. Sebelum pandemi, Unicef memprediksi ada sekitar 100 juta anak yang telah melakukan pernikahan paksa sampai 10 tahun ke depan. Angka itu kini diperkirakan meningkat hingga 10\%. Menurut Dr. Susilowati Suparto, M.H., meningkatnya angka pernikahan dini di masa pandemi Covid-19 salah satunya akibat masalah ekonomi. Kehilangan mata pencaharian yang berdampak pada kondisi ekonomi keluarga menjadi sulit,

Pernikahan merupakan suatu kesepakatan antara dua pihak yaitu pria dan wanita untuk membentuk keluarga dan dari pernikahan ini dapat meneruskan keturunan mereka. Pernikahan tidak hanya mengait dua orang yang saling mencintai tetapi juga mempersatukan dua keluarga baru dari kedua pihak. Al-Qur'an sudah menerangkan sasaran tersebut, dalam pandangan islam pernikahan merupakan konsep cinta dan kasih sayang.

Surat An-Nur ayat 32:

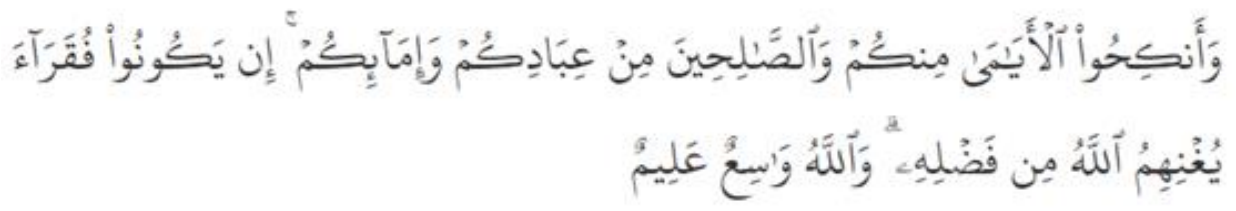

Artinya: "Nikahkanlah orang-orang yang masih membujang di antara kamu dan juga orang-orang yang layak (menikah) dari hamba-hamba sahayamu, baik laki-laki maupun perempuan. Jika mereka miskin, Allah akan memberi kemampuan kepada mereka dengan karunia-Nya. Allah Maha Luas (pemberian-Nya) lagi Maha Mengetahui."

Dalam undang undang No. 1 tahun 1974 tentang perkawinan menyatakan batas perkawinan itu usia 16 tahun bagi perempuan dan 19 tahun bagi laki-laki. Prinsip calon suami dan istri harus sudah matang jiwa serta raganya untuk melaksanakan sebuah pernikahan, supaya dapat mewujudkan pernikahan tanpa berakhir pada perceraian dan mendapatkan keturunan yang baik dan sehat. Untuk itu, pernikahan calon suami dan isteri di bawah umur harus di cegah.

Keharmonisan keluarga adalah keadaan tercapai kebahagiaan dan kebersamaan setiap anggota dalam suatu keluarga dan sedikit sekali terjadi konflik, sehingga terbentuklah keluarga yang tentram dan Bahagia. Keluarga harmonis akan tercipta jika suami istri taat pada agama, menjalankan tugas dan tanggung jawab masing-masing, saling menghormati, saling menghargai, saling mencintai, saling pemaaf, saling bekerja sama, dan saling menjaga komunikasi.

Pernikahan dini menyebabkan lahirnya keluarga-keluarga yang tidak harmonis. Pada umumnya pasangan muda keaadaan psikologisnya masih belum matang, mengakibatkan tidak stabil dalam menghadapi masalah yang timbul dalam pernikahan. Hal ini 
menyebabkan permasalahan yang timbul dalam rumah tangga tidak terselesaikan dengan baik tetapi akan menjadi semakin rumit. Umur akan mempengaruhi cara berpikir dan sikap seseorang.

Selain itu, pasangan muda juga belum matang secara sosial ekonomi. Umumnya mereka belum memiliki pekerjaan tetap sehingga kesulitan dalam ekonomi, kondisi seperti ini memicu konflik dalam rumah tangga. Tidak stabilnya emosi serta kurang pengetahuan dalam pasangan yang menikah muda.

\section{B. Rumusan Masalah}

Berdasarkan latar belakang dan batasan masalah, maka permasalahan yang akan dibahas dalam penelitian ini adalah:

1. Bagaimana gambaran pernikahan usia dini?

2. Apakah pernikahan dini memiliki pengaruh terhadap keharmonisan keluarga?

\section{Tujuan Penelitian}

Tujuan diadakannya penelitian ini, yaitu:

1. Untuk gambaran pernikahan usia dini.

2. Untuk mengetahui pengaruh pernikahan dini terhadap keharmonisan keluarga.

\section{Metode Penelitian}

Metode penelitian yang dipakai menggunakan studi pustaka serta kuantitatif.

\section{KAJIAN TEORI}

\section{A. Pernikahan}

\section{Pengertian pernikahan}

Pernikahan adalah sunnatullah yang berlaku bagi semua makhluk hidup. Ini merupakan fitrah serta kebutuhan demi berlangsungnya kehidupan. Sebagaimana yang tertulis dalam surat ads-Dzariyat ayat 49:

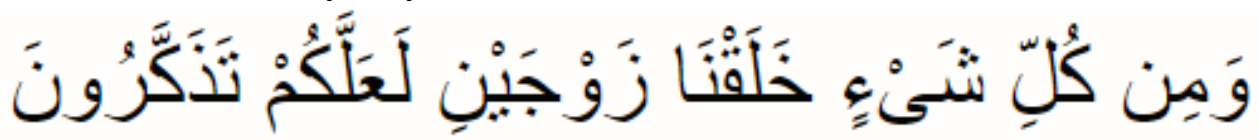

Artinya: "Dan segala sesuatu kami ciptakan berpasang-pasangan supaya kamu mengingat kebesaran Allah."

Nikah dalam bahasa al-jam'u dan al-dhamu yang artinya kumpul. Makna nikah (zawaj) bisa diartikan dengan aqdu al-tazwij yang artinya akad nikah, juga bisa diartikan (wath'u al-zaujah) bermakna menyetubuhi istri. Menurut Rahmat Hakim kata nikah berasal dari bahasa arab "nikahun" yang merupakan masdar atau asal kata dari kata kerja (fi'il madhi) "nakaha" sinonimnya "tazawwaja" kemudian diterjemahkan ke dalam bahasa Indonesia sebagai pernikahan. Pernikahan merupakan akad atau ikatan, karena dalam suatu proses pernikahan terdapat ijab dan kabul. Ijab adalah pernyataan penyerahan dari pihak perempuan, sedangkan kabul merupakan pernyataan penerimaan dari pihak lelaki. Dengan demikian, pernikahan juga bisa diartikan bersetubuh. 
Nikah atau perkawinan adalah akad antara calon suami dan istri untuk memenuhi hajat jenisnya yang diatur oleh syariah. Dengan akad ini kedua calon akan diperbolehkan sebagai suami istri. Akad merupakan ijab dari pihak wali perempuan atau wakilnya dan kabul dari pihak calon suami atau wakilnya

Menurut Muhammad Abu Ishrah akad yang memberikan faedah hukum kebolehan mengadakan hubungan keluarga (suami istri) antara pria dan wanita serta mengadakan tolong menolong dan memberbatas hak bagi pemiliknya serta pemenukah kewajiban bagi masing-masing.

UU RI No. 1 tahun 1974, pernikahan ialah ikatan lahir batin antara seorang pria dan seorang wanita sebagai suami istri dengan tujuan membentuk keluarga yang bahagia dan kekal berdasarkan Yang Maha Esa,

Pada pasal 2 Undang-Undang Perkawinan (UUP) disebutkan pernikahan adalah akad yang sangat kuat untuk mentaati perintah Allah dan melaksanakannya merupakan ibadah.

Dari beberapa pengertian diatas dapat diambil kesimpulan bahwa pernikahan adalah akad yang sangat kuat yang mengandung ketentuan hukum kebolehan hubungan seksual dengan lafadz nikah serta kata-kata yang semakna untuk membina rumah tangga yang sakinah serta untuk mentaati perintah Allah SWT, jika melakukannya merupakan ibadah.

\section{Syarat dan Rukun Nikah}

Sebelum melangkah ke jenjang pernikahan, terlebih dahulu memperhatikan halhal yang mendasar dari terlaksananya sebuah kegiatan, yaitu melengkapi syarat-syarat dan rukun-rukun dari pernikahan tersebut, rukun merupakan sesuatu yang ada untuk menentukan sah dan tidaknya suatu pekerjaan (Ibadah), seperti membasuh muka untuk wudhu, serta adanya pengantin laki-laki / perempuan dalam perkawinan. Jumhur Ulama sependapat bahwa rukun perkawinan terdiri atas:

1. Terdapat calon suami dan istri yang akan melakukan suatu pernikahan.

2. Terdapat wali dari calon wanita.

Akad nikah dikatakan sah apabila ada seorang wali atau wakil yang menikahi, berdasarkan sabda Nabi SAW:

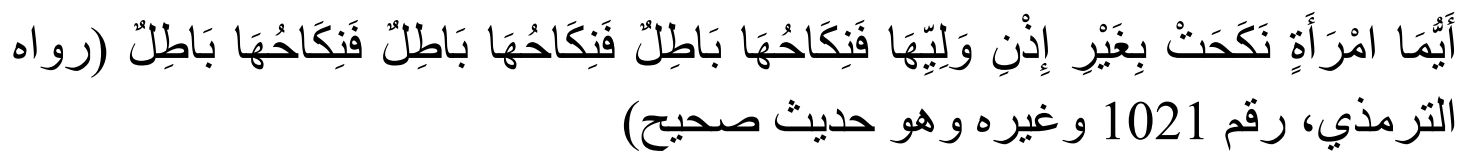

Artinya: "Wanita mana saja yang menikah tanpa izin dari walinya, maka nikahnya batal, maka nikahnya batal, maka nikahnya batal." (HR. Tirmizi, no. 1021).8

\section{Adanya dua orang saksi.}

Pelaksanaan akad nikah sah jika terdapat dua orang saksi nikah, berdasarkan Q.S Al-Baqarah: 2/282: "Dan persaksikanlah dengan dua orang saksi dari laki-laki (diantaramu)" (Q.S Al-Baqarah: 2/282)

4. Sighat akad nikah, merupakan ijab kabul yang diucapkan oleh wali atau wakil dari pihak wanita, dan dijawab oleh calon pengantin laki-laki. 
Syarat merupakan sesuatu yang harus ada untuk menentukan sah dan tidaknya perkawinan, namun tidak termasuk salah satu bagian dari hakikat perkawinan. Seperti kedua calon pengantin harus beragama Islam.

Sah adalah suatu pekerjaan (Ibadah) memenuhi rukun dan syarat. Syarat-syarat pernikahan merupakan dasar sahnya suatu pernikahan. Jika syaratnya sudah terpenuhi, pernikahan telah dikatakan sah dan segala kewajiban serta hak-hak pernikahan. Syarat pernikahan ada dua, yaitu:

Pertama, perempuan yang akan dinikahi harus halal. Jadi, bukan perempuan haram yang dinikahi, baik haram untuk sementara maupun selama-lamanya. Kedua, akad nikah wajib dihadiri para saksi. Dalam hal ini meliputi masalah-masalah sebagai berikut:

\section{Hukum mempersaksikan}

Menurut jumhur ulama' pernikahan yang tidak dihadiri para saksi adalah tidak sah.

\section{Syarat-syarat menjadi saksi}

Syarat-syarat menjadi saksi adalah berakal sehat, dewasa, dan mendengarkan omongan dari kedua belah pihak yang berakad dan memahami bahwa ucapanucapanya itu adalah sebagai ijab dan qabul pernikahan.

Adapun untuk syarat menjadi seorang saksi adalah:

- Bersifat adil

- Laki-laki

- Harus merdeka

- Harus orang islam

Syarat-syarat mempelai laki yaitu:
A. Calon suami beragama islam
B. Jelas bahwa calon suami betul laki-laki
C. Orangnya diketahui dan tertentu
D. Calon mempelai laki-laki jelas dan halal kawin dengan calon istri
E. Calon mempelai laki-laki kenal dan tahu dengan calon istri
F. Calon suami rela untuk melakukan perkawinan itu
G. Tidak sedang melakukan ihram
H. Tidak sedang memiliki istri empat
I. Tidak memiliki istri yang dilarang dimadu dengan calon istri
Syarat-syarat mempelai wanita yaitu:
A. Beragama Islam
B. Terang bahwa ia wanita, bukan khusna (banci)
C. Wanita itu tertentu orangnya
D. Halal bagi calon suami
E. Wanita itu tidak dalam ikatan perkawinan dan tidak tidak masih dalam iddah
F. Tidak dipaksa
G. Tidak dalam keadaan ihram 


\section{Hukum Nikah}

Hukum pernikahan merupakan hukum yang mengatur hubungan antara manusia dengan sesama yang menyangkut penyaluran kebutuhan biologis antara jenis, hak, serta kewajiban yang berhubungan dengan akibat perkawinan. Hukum nikah menurut para ulama adalah berdasarkan kondisi serta situasi. Hukum nikah berdasarkan kondisi dan situasi terbagi menjadi lima:

1. Wajib artinya hukum nikah akan menjadi wajib bila seseorang telah mampu baik secara fisik maupun finansial.

2. Sunnah artinya seseorang ingin memiliki anak serta tak mampu mengendalikan diri dari berbuat zina.

3. Makruh artinya jika seseorang ingin menikah tetapi tidak berniat memiliki anak, serta ia mampu menahan diri untuk berbuat zina. Dengan demikian, jika ia menikah ibadah sunnahnya akan terlantar.

4. Mubah artinya seseorang yang igin menikah tetapi mampu untuk menahan nafsu dari berbuat zina, hukumnya adalah mubah. Sementara, ia belum berniat memiliki anak serta seandainya menikah ibadah sunnahnya tidak terlantar.

5. Haram artinya seandainya ia menikah justru akan merugikan istrinya, karena tidak mampu memberi nafkah lahir dan batin. Atau jika ia menikah, mencari mata pencaharian dengan cara yang diharamkan oleh Allah, sebenarnya ia sudah berniat menikah serta mampu menahan nafsu dari zina.

Jadi, hukum pernikahan sendiri dapat disesuaikan berdasarkan keadaan satu orang yang ingin menikah. Dengan keterangan di atas, kita dapat membedakan mana hukum yang sesuai untuk kasus atau keadaan yang diharuskan maupun diharamkan untuk menikah.

\section{Hikmah dan Tujuan Pernikahan Dalam Islam}

\section{a. Hikmah pernikahan}

Islam menganjurkan umatnya untuk melaksanakan perkawinan sesuai dengan tuntunan ajaran islam tidak lepas dari keutamaan serta faedah yang terkandung di dalamnya, baik bagi diri sendiri, masyarakat, maupun bagi manusia pada umumnya. Secara sederhana, ada lima hikmah dibalik perintah menikah dalam islam:

1. Memenuhi tuntutan fitrah, islam tidak menahan serta menutupi keinginan umat muslim, bahkan melarang kehidupan umat muslim yang menolak pernikahan ataupun membujang.

2. Menghindari rusaknya moral, nafsu untuk berhubungan seksual timbul serta akan berusaha memenuhi itu dengan cara yang dilarang agama. Hal ini dapat menimbulkan rusaknya moral dan perilaku menyimpang seperti perzinaan, dan lain-lain. Menurut Ustadz Muharrar, Lc. mengatakan:

"Di antara maslahat serta hikmah menikah merupakan menjaga masyarakat dari perilaku buruk, perilaku menyimpang seperti zina, perselingkuhan, dan lain sebagainya." 


\section{Jurnal Pendidikan Sosial Keberagaman}

Print-ISSN 2355-4622 Online-ISSN 2622-9021

Vol. 8, No. 2, Desember 2021, halaman 66-80

https://juridiksiam.unram.ac.id/index.php/juridiksiam

3. Mewujudkan ketenangan jiwa, manusia akan mendapatkan jasmaniah dan rohaniah berupa kasih sayang, ketenangan, ketentraman, dan kebahagiaan hidup dalam perkawinan. Allah SWT berfirman:

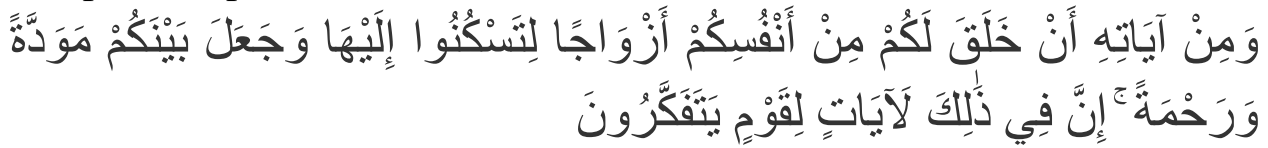

Artinya: Dan di antara tanda-tanda (kebesaran)-Nya ialah Dia menciptakan pasangan-pasangan untukmu dari jenismu sendiri, agar kamu cenderung dan merasa tenteram kepadanya, dan Dia menjadikan diantaramu rasa kasih dan sayang. Sungguh, pada yang demikian itu benar-benar terdapat tanda-tanda (kebesaran Allah) bagi kaum yang berpikir. (QS. Ar-Rum: 21)

4. Menyambung keturunan, melahirkan anak yang shalih, beriman dan bertaqwa. Anak yang cerdas emosional serta intelektualnya untuk melanjutkan syiar agama yang dibawa orangtuanya.

\section{b. Tujuan pernikahan}

Orang menikah sepantasnya tidak hanya bertujuan untuk menunaikan syahwat semata. Namun ia menikah karena tujuan berikut ini:

1. Melaksanakan anjuran Nabi shallallahu 'alaihi wa sallam dalam sabdanya: "Wahai sekalian para pemuda! Siapa diantara kalian yang telah mampu untuk menikah maka hendaknya ia menikah."

2. Memperbanyak keturunan umat, Nabi shallallahu 'alaihi wa sallam bersabda

"Menikahlah kalian dengan wanita yang penyayang lagi subur, karena (pada hari kiamat nanti) aku membanggakan banyaknya jumlah kalian di hadapan umat yang lain."

3. Menjaga kemaluan, menundukkan pandangan dari yang haram karena Allah SWT memerintahkan:

"Katakanlah (ya Muhammad) kepada laki-laki yang beriman: 'Hendaklah mereka menahan sebagian pandangan mata mereka dan memelihara kemaluan mereka, yang demikian itu lebih suci bagi mereka. Sesungguhnya Allah Maha mengetahui apa yang mereka perbuat.' Dan katakanlah kepada wanita wanita yang beriman: 'Hendaklah mereka menahan sebagian pandangan mata mereka dan memelihara kemaluan mereka...' (An-Nur: 30-31)

\section{B. Pernikahan Dini}

Pernikahan dini merupakan ikatan lahir dan batin antara suami istri di usia yang muda.

\section{Pengertian dan batasan usia dini}

Menurut World Health Organization (WHO), pernikahan dini (early married) merupakan pernikahan yang dilakukan oleh pasangan yang masih dikategorikan anakanak atau remaja yang berusia dibawah 19 tahun. Menurut United Nations Children's 
Fund (UNICEF) menyatakan pernikahan dini merupakan pernikahan yang dilaksanakan secara resmi maupun tidak yang dilakukan sebelum usia 18 tahun. Menurut UU RI Nomor 1 Tahun 1974 pasal 1 ayat 1 menyatakan bahwa pernikahan hanya diizinkan jika pria sudah mencapai umur 19 tahun dan wanita sudah mencapai umur 16 tahun, jika masih dibawah umur tersebut, maka dinamakan pernikahan dini.

\section{Hal-hal yang harus diperhatikan sebelum menikah dini}

Sebelum menikah dini sebaiknya mempersiapkan diri agar memiliki bekal untuk menjalani hidup berumah tangga serta menghindari kemungkinan buruk datang. Hal-hal yang harus diperhatikan diantaranya adalah:

1. Memiliki Kematangan Emosi

Kematangan emosi merupakan kemampuan remaja dalam mengekspresikan emosinya secara tepat dengan pengendalian diri, memiliki konsekuensi diri, serta memiliki penerimaan diri yang tinggi. Dengan memiliki kematangan emosi yang baik maka seseorang dapat menjaga pernikahannya karena mampu mengelola perbedaan yang ada dalam rumah tangga.

2. Lebih dari Sekedar Cinta

Pernikahan tidak hanya didasari cinta ataupun ketertarikan seksual saja, tetapi harus didasari pada komitmen agar tidak terjerumus pada perzinaan yang haya ingin mengikuti sunnah nabi dan mengharap ridho Allah SWT.

3. Mempunyai bekal ilmu

Banyak hal yang harus dipelajari untuk menghadapi kehidupan rumah tangga. Ada kewajiban maupun kebijakan dalam pernikahan yang menuntut kita untuk memiliki ilmunya. Untuk itu orang yang berumah tangga, butuh bekal ilmu untuk mengurangi rusaknya rumah tangga.

4. Kemampuan memenuhi tanggung jawa

Bagi seorang suami memiliki tanggung jawab untuk memenuhi kebutuhan sandang, pangan, papan. Sedangkan bagi seorang istri memiliki kewajiban untuk melayani suami dengan baik, dan masih banyak lagi tanggung jawab yang harus dipikul oleh pasangan suami istri. Untuk itu, sebelum melakukan pernikahan pasangan harus siap dengan segala tanggung jawab yang akan dipikul agar rumah tangga dapat berjalan dengan baik.

5. Kesiapan menerima anak

Dalam membentuk rumah tangga tidak hanya dituntut dalam kesiapan pernikahan, tetapi dituntut juga untuk membentuk rumah tangga, yang terdiri dari ayah ibu dan anak. Suami istri harus siap menerima anak dalam kehidupannya.

\section{Dampak Pernikahan Usia Dini}

Berbagai dampak pernikahan dini dapat dikemukakan sebagai berikut:

\section{a. Dampak negatif:}

Dampak negatif pernikahan dini sebagai berikut:

1. Dampak Biologis 


\section{Jurnal Pendidikan Sosial Keberagaman}

Print-ISSN 2355-4622 Online-ISSN 2622-9021

Vol. 8, No. 2, Desember 2021, halaman 66-80

https://juridiksiam.unram.ac.id/index.php/juridiksiam

Secara biologis alat-alat reproduksi masih dalam proses pertumbuhan menuju kematangan sehingga belum siap untuk melakukan hubungan seksual, apalagi sampai terjadi hamil serta melahirkan. Jika dipaksakan justru akan terjadi trauma.

2. Dampak Psikologis

Secara psikis belum mengerti tentang hubungan seksual, sehingga akan menimbulkan trauma yang berkepanjangan dalam jiwa dan sulit disembuhkan. Anak akan murung dan menyesali hidupnya yang berakhir dengan pernikahan yang dia sendiri tidak mengerti atas keputusan hidupnya, sehingga mengalami kesulitan untuk menjadi keluarga yang berkualitas.

3. Dampak Sosial

Pernikahan mengurangi kebebasan pengembangan diri, merasa kehilangan sebagai aset remaja yang seharusnya ikut bersama mengabdi serta bergerak di masyarakat. Tetapi karena alasan sudah berkeluarga, sehingga keaktifan mereka di masyarakat menjadi berkurang.

4. Dampak Ekonomi

Menyebabkan sulitnya peningkatan pendapatan keluarga, sehingga kegagalan keluarga dalam melewati berbagai macam permasalahan terutama masalah ekonomi serta meningkatkan resiko perceraian.

\section{b. Dampak positif:}

Dampak positif dari pernikahan dini sebagai berikut:

1. Segi Ekonomi

Dengan menikah di usia dini dapat meringankan beban ekonomi keluarga menjadi lebih hemat. Apabila pernikahan dini memang sudah terencana serta direstui oleh kedua belah pihak keluarga.

2. Bertanggung Jawab

Selain itu, mereka dapat belajar memikul tanggung jawab di usia dini. Banyak pemuda yang sewaktu masa sebelum nikah tanggung jawabnya masih kurang karena ada orang tua yang menanggung hidup mereka. Setelah menikah mereka harus mengatur urusan mereka tanpa bergantung pada orang tua.

\section{Keharmonisan Dalam Rumah Tangga}

\section{Pengertian Keharmonisan Rumah Tangga}

Keharmonisan keluarga merupakan situasi serta kondisi dalam keluarga yang di dalamnya tercipta kehidupan yang kuat, saling menghargai serta menyayangi, memiliki waktu bersama, menjalin komunikasi yang positif serta mampu mengatasi setiap permasalahan secara efektif (Defrain dan Asay, 2007).

Keluarga harmonis hanya akan tercipta dalam kebahagian salah satu anggota berkaitan dengan kebahagian anggota keluarga lainnya. Secara psikologi dapat berarti dua hal yaitu:

1. Tercapainya keinginan, cita-cita, serta harapan dari semua anggota keluarga. 
2. Sedikitnya mungkin terjadi konflik dalam pribadi sendiri maupun antar pribadi sendiri. (Sarwono, 1982)

\section{Aspek-aspek Keharmonisan Rumah Tangga}

Keluarga harmonis menurut DeFrain dan Asay (2007) memiliki beberapa aspek adalah:

1. Menciptakan kehidupan beragama, di dalam keluarga kehidupan beragama sangatlah penting karena terdapat nilai moral dan etika kehidupan.

2. Mempunyai waktu untuk bersama, baik itu hanya sekedar berkumpul, makan bersama, menemani anak bermain, dan mendengarkan masalah dan keluhan dari anggota keluarga.

3. Komunikasi yang efektif, Komunikasi yang baik dalam keluarga dapat membentuk keluarga yang harmonis, karena saling terbuka sehingga tidak ada kesalah pahaman.

4. Penghargaan serta kasih sayang sesama anggota keluarga, di dalam keluarga harus saling menghargai serta menyayangi satu sama lain.

5. Komitmen, masing-masing anggota keluarga memiliki komitmen,saling menghargai, mempercayai, saling setia serta berbagi satu sama lain.

6. Kemampuan mengatasi masalah serta krisis, mampu mengatasi Kualitas serta kuantitas konflik yang minim, jika dalam keluarga sering terjadi perselisihan serta pertengkaran maka suasana dalam keluarga tidak lagi menyenangkan. Dalam keluarga harmonis setiap anggota keluarga menyelesaikan masalah dengan kepala dingin serta mencari penyelesaian terbaik dari setiap permasalahan.

\section{Faktor Penentu Keharmonisan Dalam Rumah Tangga}

Gunarsa (2002) menyatakan bahwa suasana rumah dapat mempengaruhi keharmonisan keluarga. Suasana rumah merupakan kesatuan yang serasi antara pribadi-pribadi, kesatuan yang serasi antara orangtua serta anak. Jadi, suasana rumah yang menyenangkan akan tercipta bagi anak bila terdapat kondisi:

a. Anak dapat merasakan bahwa ayah serta ibunya terdapat saling pengertian, kerjasama yang serasi serta saling mengasihi antara satu dengan yang lainnya.

b. Anak dapat merasakan bahwa orang tuanya mau mengerti serta dapat menghayati pola perilakunya, dapat mengerti apa yang diinginkannya, serta memberi kasih sayang secara bijaksana.

c. Anak dapat merasakan bahwa saudara-saudaranya, mau memahami serta menghargai dirinya menurut kemauan, cita-citanya, serta anak dapat merasakan kasih sayang yang diberikan saudara-saudaranya.

Faktor lain dalam keharmonisan keluarga merupakan kehadiran seorang anak dari hasil perkawinan satu pasangan. Gunarsa (2002) menyebutkan kehadiran seorang anak ditengah keluarga merupakan hal yang dapat lebih mempererat jalinan cinta kasih pasangan 


\section{METODE PENELITIAN}

\section{A. Jenis Penelitian}

Penelitian ini menggunakan metode penelitian kuantitatif. Penelitian kuantitatif merupakan suatu proses menemukan pengetahuan yang menggunakan data berupa angka sebagai alat menemukan keterangan mengenai apa yang ingin diketahui oleh peneliti. Angka yang terkumpul sebagai hasil penelitian kemudian dapat dianalisis menggunakan metode statistik.

\section{B. Subjek Penelitian}

Subjek penelitian atau responden merupakan pihak-pihak yang dijadikan sebagai sampel dalam sebuah penelitian. Adapun subjek dalam penelitian ini adalah orang yang telah melakukan pernikahan dini.

\section{Objek Penelitian}

Objek penelitian merupakan sasaran isu yang akan dibahas serta yang akan dilakukan penelitian atau yang akan diselidiki menurut riset sosial. Dalam hal ini yang dijadikan objek penelitian kami adalah masyarakat jakarta yang sudah melakukan pernikahan dini.

\section{Metode Pengambilan Data}

Pada penelitian ini, peneliti menyebarkan link google form kepada subjek penelitian yang berisi pertanyaan-pertanyaan mengenai pernikahan dini yang mereka jalani. Dalam pelaksanaan pengumpulan data, peneliti mengajukan beberapa pertanyaan kepada masyarakat Jakarta yang telah melakukan pernikahan dini, Adapun pertanyaannya sebagai berikut:

1. Apakah wajib pernikahan usia dini dimasa sekarang?

2. Menurut anda pernikahan dini dilakukan pada usia berapa?

3. Dengan siapa anda tinggal sekarang?

4. Bagaimana keadaan rumah tangga hingga saat ini?

5. Apakah ada masalah yang terjadi dalam rumah tangga yang menimbulkan konflik?

6. Apakah pernikahan dini berpengaruh terhadap keharmonisan rumah tangga?

\section{E. Metode Analisis Data}

Penelitian ini merupakan penelitian kuantitatif yaitu menggambarkan mengolah data yang berupa angka-angka yang disajikan dalam bentuk table. Data kuantitatif dianalisis dengan menggunakan metode analisis sebagai berikut:

1. Indukatif

Indukatif merupakan teknik menganalisis data yang bertitik tolak dari hal yang bersifat khusus kemudian menarik kesimpulan yang bersifat umum. Hal ini sesuai dengan pendapat Nana Sudjana yang menyatakan:

"Proses berpikir induktid adalah kebalikan dari berpikir dedukatif yakni pengambilan kesimpulan mulai dari pernyataan atau fakta-fakta khusus menuju kepada kesimpulan yang bersifat umum"

2. Dedukatif

Dedukatif suatu cara berpikir yang digunakan dengan melalui cara berfikir umum untuk menarik yang bersifat umum untuk menarik kesimpulan khusus. 
Sutrisno Hadi M. mengemukakan pendapatnay tentang berpikir deduktif sebagai berikut, dengan defuktif kita berangkat dari pengetahuan yang umum kita hendak menilai sesuatu yang bersifat khusus.

Sedangkan untuk menganalisis data yang bersifat kuantitatif yang diperoleh melalui angket maka digunakan rumus persentase dari hasil penelitian.

Adapun rumus persentase yaitu:

$$
P=\frac{F}{N} \times 100 \%
$$

Keterangan:

F : Frekuensi yang sedang dicari persentasenya

$\mathrm{N} \quad$ : Jumlah frekuensi/banyaknya frekuensi

$\mathrm{P} \quad$ : Angka persentase

\section{HASIL PENELITIAN}

\section{A. Tanggapan Masyarakat Yang Telah Melakukan Pernikahan Dini Terhadap Keharmonisan Keluarga}

Agama mengajarkan kepada manusia untuk segera menikah jika telah sanggup untuk melaksanakannya, dalam al-Quran di sebutkan bahwa manusia diciptakan berpasangpasangan, hal ini yang menjadi permasalahan pada usia berapa dan bagaimana manusia di pandang layak untuk menikah.

Pernikahan dini merupakan pernikahan yang dilakukan ketika seseorang belum menginjak umur 16 tahun untuk wanita serta 19 tahun bagi pria. Idealnya usia pernikahan yang dianggap sudah memenuhi standar yaitu bagi perempuan diatas umur 20 tahun dan bagi laki-laki 25 tahun, usia tersebut apabila di lihat dari sisi mental dan kedewasaaan seseorang.

Peneliti mendapatkan jawaban 14 responden yang terdiri dari 7 pasang suami istri. Untuk itu berikut peneliti sajikan data yang peneliti dapatkan.

\section{Apakah wajib pernikahan usia dini dimasa sekarang}

\begin{tabular}{|l|l|l|l|}
\hline No & Alternatif Jawaban & Frekuensi & Presentase \\
\hline 1 & Wajib & 13 & $92,9 \%$ \\
\hline 2 & Tidak & 1 & $7,1 \%$ \\
\hline
\end{tabular}

Sumber data: Hasil link google form yang disebarkan pada 7 pasangan pernikahan dini

Berdasarkan tabel diatas diketahui bahwa masi banyak masyarakat yang beranggapan pernikahan dini masi wajib, yang menjawab wajib berjumlah 13 orang dengan persentase $92,9 \%$, dan yang menjawab tidak berjumlah 1 orang dengan persentase $7,1 \%$.

Menurut anda pernikahan dini dilakukan pada usia berapa

\begin{tabular}{|l|l|l|l|}
\hline No & Alternatif Jawaban & Frekuensi & Presentase \\
\hline 1 & $<16$ Tahun & 7 & $50 \%$ \\
\hline 2 & $>16$ Tahun & 2 & $14,3 \%$ \\
\hline 3 & $<20$ Tahun & 5 & $35,7 \%$ \\
\hline
\end{tabular}

Sumber data: Hasil link google form yang disebarkan pada 7 pasangan pernikahan dini 


\section{Jurnal Pendidikan Sosial Keberagaman}

Print-ISSN 2355-4622 Online-ISSN 2622-9021

Vol. 8, No. 2, Desember 2021, halaman 66-80

https://juridiksiam.unram.ac.id/index.php/juridiksiam

Berdasarkan tabel diatas diketahui bahwa pernikahan di usia dini yaitu, <16 tahun berjumlah 7 orang dengan persentase $50 \%$, >16 tahun berjumlah 2 orang dengan persentase $14,3 \%$, <20 tahun berjumlah 5 orang dengan persentase $35,7 \%$ dengan demikian masyarakat masi ada yang melakukan pernikahan dini.

Dengan siapa anda tinggal ketika sudah menikah

\begin{tabular}{|l|l|l|l|}
\hline No & Alternatif Jawaban & Frekuensi & Presentase \\
\hline 1 & Bersama orang tua & 10 & $71,4 \%$ \\
\hline 2 & Rumah mertua & - & - \\
\hline 3 & Rumah sendiri & 4 & $28,6 \%$ \\
\hline
\end{tabular}

Sumber data: Hasil link google form yang disebarkan pada 7 pasangan pernikahan dini

Berdasarkan tabel diatas diketahui bahwa yang bertempat tinggal ketika sudah menikah, bersama orang tua berjumlah 10 orang dengan persentase $71,4 \%$, rumah sendiri berjumlah 4 orang dengan persentase $28,6 \%$ dan rumah mertua $0 \%$.

\section{Bagaimana keadaan rumah tangga hingga saat ini}

\begin{tabular}{|l|l|l|l|}
\hline No & Alternatif Jawaban & Frekuensi & Presentase \\
\hline 1 & Harmonis & 9 & $64,3 \%$ \\
\hline 2 & Cerai & - & - \\
\hline 3 & Kurang harmonis & 2 & $14,3 \%$ \\
\hline 4 & Masih, tapi tidak harmonis & 3 & $21,4 \%$ \\
\hline
\end{tabular}

Sumber data: Hasil link google form yang disebarkan pada 7 pasangan pernikahan dini

Berdasarkan tabel diatas diketahui bahwa keadaan rumah tangga pernikahan dini yaitu, Harmonis berjumlah 9 orang persentase 64,3\%, masih, tapi tidak harmonis berjumlah 3 orang dengan persentase $14,3 \%$, kurang harmonis berjumlah 2 orang dengan persentase $14,3 \%$, dan cerai $0 \%$.

Apakah ada masalah yang terjadi dalam rumah tangga yang menimbulkan konflik

\begin{tabular}{|l|l|l|l|}
\hline No & Alternatif Jawaban & Frekuensi & Presentase \\
\hline 1 & Ekonomi & 5 & $41,7 \%$ \\
\hline 2 & Komunikasi & 3 & $25 \%$ \\
\hline 3 & Ketidakhadiran anak & - & - \\
\hline 4 & Selingkuh & 2 & $16,7 \%$ \\
\hline 5 & Saat penyatuan pendapat & 2 & $16,6 \%$ \\
\hline
\end{tabular}

Sumber data: Hasil link google form yang disebarkan pada 7 pasangan pernikahan dini

Berdasarkan tabel diatas diketahui bahwa konflik yang terjadi dalam rumah tangga yaitu, ekonomi berjumlah 5 orang dengan persentase 41,7\%, komunikasi berjumlah 3 orang dengan persentase $25 \%$, selingkuh berjumlah 2 orang dengan persentase $16,7 \%$, saat penyatuan pendapat berjumlah 2 orang dengan persentase 16,6\%, dan ketidakhadiran anak $0 \%$.

Apakah pernikahan dini berpengaruh terhadap keharmonisan rumah tangga

\begin{tabular}{|l|l|l|l|}
\hline No & Alternatif Jawaban & Frekuensi & Presentase \\
\hline 1 & Berpengaruh & 11 & $78,6 \%$ \\
\hline
\end{tabular}




\begin{tabular}{|l|l|l|l|}
\hline 2 & Kurang berpengaruh & 2 & $14,3 \%$ \\
\hline 3 & Tidak berpengaruh & 1 & $7,1 \%$ \\
\hline
\end{tabular}

Sumber data: Hasil link google form yang disebarkan pada 7 pasangan pernikahan dini

Berdasarkan tabel diatas diketahui bahwa dari 7 pasangan responden yang menyatakan berpengaruh berjumlah 11 orang dengan persentase $78,6 \%$, menyatakan kurang berpengaruh berjumlah 2 orang dengan persentase $14,3 \%$, dan yang menyatakan tidak berpengaruh berjumlah 1 orang dengan persentase $7,1 \%$. Jadi dengan demikian bahwa pernikahan dini berpengaruh terhadap keharmonisan dalam rumah tangga. Dimana perlu diketahui bahwa keharmonisan suami istri dalam rumah tangga adalah bentuk pencapaian keberhasilan dan kebahagiaan yang tidak semua suami istri dapat memperoleh.

\section{KESIMPULAN DAN SARAN}

\section{A. Kesimpulan}

Bedasarkan hasil penelitian yang telah dilakukan, dapat disimpulkan sebagai berikut:

1. Pernikahan dini dengan keharmonisan dalam rumah tangga di masyarakat masi banyak yang menimbulkan konflik. Dari 7 pasangan responden yang menyatakan masalah ekonomi berjumlah 5 orang dengan persentase $41,7 \%$, masalah komunikasi berjumlah 3 orang dengan persentase $25 \%$, selingkuh berjumlah 2 orang dengan persentase $16,7 \%$, saat penyatuan pendapat 2, dengan persentase $16,6 \%$.

2. Pernikahan dini memiliki pengaruh terhadap keharmonisan rumah tangga di masyarakat. Dari 7 pasangan responden, yang menyatakan berpengaruh berjumlah 11 orang dengan persentase $78,6 \%$, menyatakan kurang berpengaruh bejumlah 2 dengan persentase $14,3 \%$, dan yang menyatakan tidak berpengaruh berjumlah 1 dengan persentase $7,1 \%$.

Berdasarkan data di atas, dapat disimpulkan bahwa pernikahan dini memiliki pengaruh terhadap keharmonisan rumah tangga. Pernikahan dini juga dikatakan dapat mengakibatkan banyak konflik yang terjadi di dalam rumah tangga. Hal ini disebabkan oleh belum stabilnya emosi yang dimiliki baik dari pihak suami maupun pihak istri.

B. Saran

Terwujudnya keluarga yang harmonis merupakan hal yang harus menjadi pertimbangan setiap pasangan yang hendak melakukan pernikahan. Berkaitan dengan penelitian ini, berikut saran saran yang dapat penulis sampaikan:

1. Bagi para remaja yang hendak melangsungkan pernikahan, hendaknya mempertimbangkan beberapa hal seperti kesiapan fisik, ilmu, mental, serta kesiapan ekonomi.

2. Bagi orang tua agar selalu memperhatikan Pendidikan anak agar adanya proses pendewasaan serta menikah pada usia yang seharusnya. Selain itu, bagi orang tua agar selalu memperhatikan pergaulan anak-anaknya agar tidak terjadi pergaulan bebas yang dapat menyebabkan anak menikah dini. 


\section{Jurnal Pendidikan Sosial Keberagaman}

Print-ISSN 2355-4622 Online-ISSN 2622-9021

Vol. 8, No. 2, Desember 2021, halaman 66-80

https://juridiksiam.unram.ac.id/index.php/juridiksiam

\section{DAFTAR PUSTAKA}

(UNPAD), K. K. (2020). Pernikahan Dini di Indonesia Meningkat di Masa Pandemi. Retrieved from https://www.unpad.ac.id/2020/07/pernikahan-dini-di-indonesia-meningkat-dimasa-pandemi/.

Anonim. (2021). Hikmah pernikahan dalam yang dijelaskan alquran dan hadist. Retrieved from Kumparan: https://kumparan.com/berita-hari-ini/hikmah-pernikahan-dalamislam-yang-dijelaskan-alquran-dan-hadist-1wWIYNJZc0O/full

Eka, D. (2017). Pengaruh Pernikahan Dini Terhadap Keharmonisan Keluarga dan Pola Pengasuhan anak di Desa Sukaraja Tiga, Kecamatan Marga Tiga, Kabupaten Lampung Timur. . Retrieved from http://repository.uma.ac.id/bitstream/123456789/2005/5/128600338_file5.pdf

Fauziah, L. (2011). Pembagian Harta Bersama Pasangan Nikah Yang Bercerai. Retrieved from http://etheses.uin-malang.ac.id/1318/6/07210050_Bab_2.pdf.

Hariswandi. (2011). Tujuan dan hikmah pernikahan . Retrieved from https://hariswandi.wordpress.com/2011/10/20/tujuan-dan-hikmah-pernikahan/

Indonesia, U. (2019). Undang- Undang Nomor 16 Tahun 2019. Retrieved from https://jdihn.go.id/files/4/2019uu016.pdf.

Kembaren, N. (2016). Perbedaan Keharmonisan Keluarga Ditinjau Dari Istri Yang Bekerja Dan Tidak Bekerja. . Retrieved from http://repository.uma.ac.id/bitstream/123456789/2005/5/128600338_file5.pdf

Malinda, K. (2020). Faktor Keharmonisan Keluarga Pada Istri Yang Bekerja. Retrieved from http://repository.iainbengkulu.ac.id/4412/1/SKRIPSI\%20KARTIKA\%20pdf.pdf .

Tricky. (2017). 6 Hal yang Harus Dipertimbangkan Sebelum Menikah Muda. Retrieved from https://kumparan.com/tricky-tricky/pertimbangkan-6-hal-ini-sebelum-kamumemutuskan-menikah-muda-1514521846044.

Yasmin, P. (2019). 5 Hukum Nikah Dalam Islam Yang Wajib. Retrieved from https://wolipop.detik.com/wedding-news/d-4783153/5-hukum-nikah-dalam-islamyang-wajib-diketahui?_ga=2.37358368.1465692806.1635300477976092570.1610075664.

Zainurrahma, L. (2019). Faktor-Faktor Yang Berhubungan Dengan Pernikahan Dini Di Kecamatan Playen Kabupaten Gunungkidul Tahun 2018 . Retrieved from http://eprints.poltekkesjogja.ac.id/2249/3/BAB\%20II_Latifa\%20FZ_Reg\%20A.pdf. 